\title{
The Normative Character of Monastic Exemption in the Early Medieval Latin West
}

\author{
Kriston R. Rennie*
}

This paper examines the normative character of monastic exemption in the Latin West, that is to say, the negotiated interaction between monasteries and bishops. In tracing the formation and development of exemption privileges between the fifth and ninth centuries, it argues for an emerging pattern under the Franks that proved central to developing notions of spiritual and physical protection. As a consequence of this novel mentality, a monastery's relationship with its surrounding environment became characterised by greater degrees of freedom and protection than ever before. This unique transformation took time to develop, however, forging alliances that effectively shifted individual monasteries away from their Frankish protectorate towards the spiritual centre in Rome. The consequences of this landmark shift, it is argued, benefited the early medieval papacy in its burgeoning claims of centralized power and legitimacy.

Keywords: monasticism; exemption; immunity; papacy; protection; Carolingian; Merovingian

The history of monastic exemption in the Latin West is not a story of exclusion; it only appears that way. As Timothy Reuter and Chris Wickham explained, »exemption means closeness to the centre, not distance from it. ${ }^{1}$ This curious paradox raises the question of what monastic exemptions were meant to achieve - both for the beneficiary and the grantor, the recipient monastery and the donor. It highlights the need to understand the contemporary meaning and political currency of these privileges, giving due attention to individual circumstance, initiative, and context. It also casts doubt on a familiar historiographical narrative that positions monastic exemptions in particular as key instruments of growing monastic emancipation from both secular and diocesan control. ${ }^{2}$ Indeed, treated as soffensive and rdefensiver weapons against episcopal abuses, they are frequently (mis-) represented as de facto conservators and guarantors of ecclesiastical liberty< (e.g., libertas ecclesiae). ${ }^{3}$ This popular interpretation conveys a backwards (teleological) reading of monastic exemption, in which

* Correspondence details: Kriston R. Rennie, University of Queensland, School of Historical and Philosophical Inquiry, St Lucia, QLD 4072, Australia. Email: k.rennie@uq.edu.au.

1 Wickham and Reuter, Introduction, 15. See also Remensnyder, Remembering Kings Past, 209.

2 See especially Schreiber, Kurie und Kloster im 12. Jahrhundert, 2.258; ibid, Kluny und die Eigenkirche, 412-418; Lemarignier, Political and Monastic Structures, 112. For some convincing counter-arguments, see Tellenbach, Church in Western Europe, 116; Brackmann, Zur politischen Bedeutung der kluniazensischen Bewegung, 21-27; Sackur, Cluniacenser, 2.440-449, 464-465; Fliche, La réforme Grégorienne, 1.39-60; Tellenbach, Church, State, and Christian Society, v-xvii, 42-47, 76-85, 93-95, 186-192; Cantor, Crisis of Western Monasticism, 61; Cowdrey, Cluniacs, xiv, n.1.

3 Falkenstein, Papauté et les abbayes françaises, 1. 
the papacy appears as inevitably triumphant. ${ }^{4}$ In the broader institutional development of exemption, however, a more organic picture emerges, one whose canvas reveals incremental changes in the external governance of medieval monasteries. The outcome of these transformations, it will be argued, contributed to defining the snormative character of monastic exemption, whose cumulative development from fiscal immunity to combined privileges of freedom and protection spans many early medieval centuries.

\section{The purpose of monastic exemption}

Let me begin with a brief consideration of purpose and intention. Privileges of monastic exemption, which defined a monastery's relationship with the bishop and his diocese, almost uniformly emphasised speace and stranquillity as their fundamental objectives. ${ }^{5}$ These pre-requisites for the observance of spiritual life were not just the concern of monastic communities; they were indisputable conditions acknowledged and supported by secular and ecclesiastical rulers alike. As many contributors to this special issue have demonstrated, their individual principles reveal a co-operative process, contributing to - and helping historians better understand - transforming power structures and nascent institutions. In one sense, this desired outcome (both medieval and modern) helps explain an exemption's raison d'être, the effects of which were seen as benefiting medieval society more generally. There are some basic assumptions underpinning exemptions, namely the notion that limiting one party freed another from an unnecessary burden; that bishops and kings wanted to interfere, and indeed were interfering, in a monastery's spiritual or economic affairs; and that social behaviours (perceived or real) were threatening the status quo - an imagined ideal of relations between the monastery and its surrounding community in a time when such relationships were themselves taking shape across early medieval Europe.

According to a privilege of monastic exemption preserved in the Formulary of Marculf, a collection of formula or sample documents written in Francia c.700, a monastery's harmonious existence was a pre-requisite to ensuring the "happiness of the land and the tranquillity of the king." For this reason, numerous charters from Merovingian and Carolingian Francia (sixth to ninth centuries) were explicitly concerned with the protection intended for monastic property: as a consequence of a grant of an exemption privilege to a monastery, as this formula stated, the bishop was bound never to infringe on any gifts, villas, unfree servants, »or anything or anybody. « ${ }^{6}$ He should never diminish any of the monastery's property

4 See especially, Goetting, Klösterliche Exemtion, 105; Schreiber, Kurie und Kloster im 12. Jahrhundert, 65-68; Knowles, Monastic Order in England, 572. For a good critique of this problematic methodological position, see Kölzer, Bonifatius und Fulda, 43; Kéry, Klosterfreiheit und päpstliche Organisationsgewalt, 84-86, 95-97.

5 For a cogent scholarly distinction between rexemption On the latter's fiscal and judicial (technical) characteristics, see Murray, Merovingian Immunity Revisited, 915917.

6 Marculfi Formulae, I. 2, ed. Zeumer, 41-43. 
under the pretext of an exchange, or take away anything out of the ornaments of the [divine] service and the offerings presented at the altar, or presume to go into this monastery and its cells in any circumstances other than to celebrate mass, if that is the will of the abbot and his congregation, without any expense on their part, so that, according to the wishes of the delegation and this solemn document, all [of the property given] there may benefit this monastery more easily, without any interference. ${ }^{7}$

In matters pertaining to the law, no judicial authority could interfere »in order to hear legal cases or to collect anything there." In all, the extent of such privileges promised full immunity to the monastic community, which translates here into receiving "all dues being conceded to themselves; and whatever our fisc could perhaps have expected from the persons, whether free or unfree, who live in their fields or anywhere [on their lands] is to benefit them in its entirety... $\ll^{8}$ According to this formula, the conferral of monastic exemption deliberately kept both the king and the bishop at a safe distance from the monastery. This was the accepted standard - a theoretical commonplace of effective ecclesiastical governance in the pursuit of the vita religiosa and a stable/secure Christian society.

Complete separation of a monastery from the diocesan bishop, however, was a spiritual, disciplinary, and administrative impracticality. The local bishop continued to provide necessary services throughout his diocese, a provision that traditionally subjected monks and monasteries to his jurisdictional authority. The nature of this relationship, especially as it related to matters of abbatial election, visitation, and ordination, was famously defined at the council of Chalcedon in 451. Canon 4 in particular outlined a notion of diocesan jurisdiction and responsibility that was later confirmed at the Merovingian (royal) councils of Agde (506) and Orleans (511). ${ }^{9}$ Stating explicitly that "the monks in every city and district shall be subject to the bishop ...", this canon likewise emphasised his role in "the needful provision for the monasteries. $\aleph^{10}$ For in essence, as the canon further stipulated, "those who truly and sincerely enter in the solitary life are to be accorded due honour.« Therefore, to prevent unnecessary and unwanted disturbances, which might disrupt churches and/or public affairs, the bishop was necessarily responsible for the improvement of discipline and the inalienability of ecclesiastical property.

7 Marculfi Formulae, I. 2, ed. Zeumer, 42: ...vel aliquid quasi per commutationes titulum minuari, aut de ministerii ornamenta vel de offertione in altario inlata abstollere; nec ad ipso monastirio $m$ vel cellolas eius nisi tantum pro lucranda oratione, ipsud si fuerit cum volontate abbatis vel eius congregatione, absque dispendio eorum, aliter accedere penitus non presumat; quo facilius secundum delegationibus votum vel huius seriae auctoritatem ad ipso monastirio absque ullius inquietudine ibidem cuncta proficiant in augmentis.

8 Marculfi Formulae, I. 2 ed. Zeumer, 41-43.

9 Concilia Galliae, canon 27, ed. Munier, 205; cf. Szaivart, Entstehung und Entwicklung, 268. Concilia Galliae, canon 19, ed. Munier, 10: Abbates...in episcoporum potestate consistant...Monachi autem abbatis omni se oboedientiae devotione subiaciant. cf. Ewig, Beobachtungen zu den Klosterprivilegien, 54-55.

10 Price and Gaddis, Acts of the Council of Chalcedon, 3.95-96. On its influence see Ueding, Kanones von Chalkedon, 2.569-676. 


\section{The development of monastic exemption}

This balanced intervention in monastic affairs influenced the developing law of exemption in late Antiquity and the early Middle Ages. Its provisions were confirmed at many subsequent church and Frankish councils between the sixth and ninth centuries, suggesting both their importance and wide dissemination throughout western Christendom. ${ }^{11}$ This solid body of conciliar and legal evidence for the early Middle Ages positions the monastery and its inhabitants firmly within the bishop's care of souls (cura), command (ordinatio), and administration (dispositio). Yet significantly, the existence and repetition of conciliar prescriptions down the centuries does not strictly imply subordination to episcopal rule, at least not to the detriment of a monastery's internal spiritual objectives. Indeed, from the origins of a western monastic tradition, exemption created an administrative, spiritual, and judicial bond between a monastery and its diocesan bishop.

In practice, the bishop provided a dominant force in realising this outcome. This harmonious, working relationship within the diocese was certainly visible in the seventh century from the so-called repiscopal privileges (Bischofsprivilegien) that were issued by a number of Frankish bishops for monasteries in their diocese: Bishop Burgundafaro of Meaux for Rebais $(637)^{12}$; Bishop Landeric of Paris for Saint-Denis (653/55) ${ }^{13}$; Bishop Audobert of Paris for Saint-Maur-des-Fossés (645) ${ }^{14}$; Bishop Emmo of Sens for Sainte-Colombe (660 and 695/96) and Saint-Pierre-le-Vif (660) ${ }^{15}$; Bishop Audomar of Thérouanne for Saint-Bertin and Sithiu $(663)^{16}$; Bishop Numerian of Trier for St Dié $(663 / 75)^{17}$; Bishop Berthefrid of Amiens for Corbie (664) ${ }^{18}$; Bishop Drauscius of Soissons for Saint-Médard at Soissons (667) $)^{19}$; Bishop Aredius of Vaison for Groseaux (683) ${ }^{20}$; Bishop Aiglibert of Le Mans for Notre-Dame in Le Mans (683) $)^{21}$; Bishop Bertrand of Châlons for Montier-en-Der (693) ${ }^{22}$; and Bishop Agérard of Chartres for Notre-Dame in Blois (696). ${ }^{23}$ The renunciation of certain political, spiritual, and administrative rights underscores a clear pattern for privileges between bishops and monasteries in Merovingian Francia, from which evidence Eugen Ewig mapped his classic interpretation of `big exemption< (grosse Freiheit) and slittle exemption` (kleine Freiheit). ${ }^{24}$ In

11 For example, the councils of Epaône (September 517), Orleans (533 and 541), Arles (554), Tours (567), Chalon-sur-Saône (647/653), and Ver (755).

12 See Pontal, Synoden im Merowingerreich, 204-210.

13 Diplomatum imperii I, ed. Pertz, no.85, 218.

14 Diplomatum imperii I, ed. Pertz, no.87, 225-227.

15 Diplomata II, ed. Pardessus, no. 275, 39.

16 Diplomatum imperii I, ed. Pertz, no.101, 260-261; Diplomata II, ed. Pardessus, no.344, 123.

17 Diplomata II, ed. Pardessus, no.360, 147f.

18 Diplomata II, ed. Pardessus, no.345, 126.

19 Ewig, Formular von Rebais, 471; cf. Schwarz, Iurisdicio und Condicio, 70-71.

20 Diplomata II, ed. Pardessus, no.401, 191-195.

21 Diplomata II, ed. Pardessus, no. 451, 253-255.

22 Diplomata II, ed. Pardessus, no.423, 221; cf. Cartulary of Montier-en-Der, 4.ed./trans. Bouchard, 52-58.

23 Diplomata II, ed. Pardessus, no. 435, 234-236.

24 See Ewig, Beobachtungen zu den Klosterprivilegien, 58ff.; Rio, Formularies of Angers and Marculf, 128-129; Kölzer, Bonifatius und Fulda, 43. 
the former case, the bishop might willingly grant (in the fullest sense) protection for the monastery's property, freedom for abbatial election, freedom to perform rites and ordination, jurisdictional independence from the diocesan bishop and freedom from tithes. In its stricter sense (the latter case), the bishop might retain his right to perform ordinations, consecrations, and blessings - a role in the life and governance of the monastery, which weakened significantly in the following four centuries (c.700-c.1100).

The formation of episcopal care and responsibility in the early Middle Ages runs parallel to the history of monastic exemption. In addition to the early conciliar legislation (mentioned above), monastic rules also played some part in the development of exemption. Chapter 64 of the sixth-century Rule of St Benedict - later the most influential guide to monastic life - determined the bishop's role in a key element of a monastery's internal affairs, his influence on "The Appointment of the Abbot" (De ordinando abbate). ${ }^{25}$ The bishop's territorial jurisdiction over religious communities meant that he had an interest in the quality of the abbatial candidates, a role best exemplified in the formulaic episcopal privileges granted to Rebais (637), Saint-Médard at Soissons (666), Corbie (667), Galilea (667), Saint-Colombe (670), Montier-en-Der (692), and Novalesa (728). ${ }^{26}$ While the bishop's role was notably limited in matters of abbatial election, his judicial force was still recognised in matters of disobedience, the sudden death of an abbot, or electoral mistakes. ${ }^{27}$ Following the arrival in Burgundy of the Irish monk, Columbanus (d. 615) - a figure responsible for foundations at Luxeuil and Bobbio - a new measure of spiritual freedom within the monastery was introduced, which challenged the authority of many local bishops. ${ }^{28}$ As reflections on the internal spiritual and administrative governance of monastic life, changing regulations served to define more coherently the monastery's political and legal position within the wider diocesan structure. For this reason, Frankish kings were equally invested in preserving the monastic life. Alongside bishops, they too issued privileges of exemption to monasteries, aimed primarily at preventing the exploitation of ecclesiastical persons or properties placed under their direct protection. From antiquity, according to Marculf's formulary, monasteries had remained "under the privilege of freedom. ${ }^{29}$ Owing precisely to the decrees of royal sanction, they enjoyed peace, salvation, and validity for both present and future purposes. The nature of this protection resembles another formula in Marculf's collection, which offers royal protection for properties, retainers, and persons $(I, 24)$ - that is, "to those who are known to be in need of it. ॥ $^{30}$ This Merovingian template goes further to protect people and properties from "unlawful attacks of evil men, so that the said church - or monastery - shall remain in peace along with all its property, under the protection [mundeburdium] and defence [defensione] « of the mayor of the palace or his delegate. Cast in this light, the exemption functions as a diplomatic axis for

25 La règle de Saint Benoît, II,648-653.

26 Hallinger, Regula Benedicti 64, 121, esp. n. 2.

27 La règle de Saint Benoît, II, pp.648-53; La règle du maître, ed./trans. de Vogüé, cc. 92-94; cf. Szaivert, Die Entstehung und Entwicklung, 273.

28 O'Hara, Vita Columbani in Merovingian Gaul, 140-143; Fox, The Bishop and the Monk, 179-181; Dunn, Emergence of Monasticism, 158-160; Bittermann, Influence of Irish Monks, 234; Wood, Merovingian Kingdoms, 186; Ewig, Formular von Rebais, 456-484. For some contemporary examples see Diplomata II, ed. Pardessus, nos 254, 275, $333,345,360,514,543,596$.

29 Marculfi Formulae, ed. Zeumer, I. 1.

30 Marculfi Formulae, ed. Zeumer, I. 24. 
early medieval politics: it bound the monastery to its diocesan bishop, and the bishop to his (secular) superior, the mayor of the palace or the king. ${ }^{31}$ As a mechanism of power, moreover, it opened the doors for more binding political relationships between the monastery and the world it inhabited.

The exemption's dominant character, therefore, was fast becoming scontrol. Whoever possessed the authority to issue privileges was displaying their ability to govern. In this way, the granting of specific rights and liberties to monasteries was a "gesture of authority « ${ }^{32}$ openly exercised by generations of secular rulers and bishops, with perceived advantages to both parties. What this means in practice is the key question - a consideration that necessarily introduces the developing idea of sprotection< (mundeburdium/tuitio/defensio) into the equation. Although visible in the charter evidence and language from the early seventh century, the significance of protection in monastic exemption charters becomes clearer at the council of Compiègne (757), convened under Bishop Chrodegang of Metz, where privileges for the monastery of Gorze were first issued. ${ }^{33}$ Presenting an exemption that was deliberately protective, the privileges for this monastery permitted episcopal visitation of the monastery 'when it pleased the bishop; protected the bishop's rights of ordination and remuneration; required the bishop's consent and will in matters of abbatial election ${ }^{34}$; and ultimately subjected the monastery to the bishop. ${ }^{35}$

Notwithstanding the traditional rights espoused in its text, the privilege for Gorze is considered unique and unprecedented. Its inclusion of protection demonstrates what Barbara Rosenwein called a "sea change - from prohibition to control.« ${ }^{36}$ That is to say that this mid eighth-century exemption balanced episcopal control over the monastery with the bishop's duty of care in securing its general wellbeing. Rather than defining the prohibitions on episcopal intervention (i.e., what the bishop could not do) - as had been customary in monastic exemption charters - the privilege instead emphasised the bishop's rights to intervene (i.e., what he could do). With echoes of Chalcedon and the first Marculf formula, the monastery of Gorze obtained its freedoms through the joint promise of subjection and protection. In this way, as the charter relates, the monastery was subject "to the protection and safeguard of the church of Saint Stephen of Metz." This association permitted the monks continued prayer "for the life and safety of the kingdom, for the stability of the kingdom of the Franks, for their bishops, and for those placed under them. « ${ }^{37}$

Physical protection was an emerging theme in this relationship. Under the Frankish rulers Charlemagne and Louis the Pious, the granting of monastic immunity was intimately connected to notions of protection, defined formulaically in the charter evidence as "immunity and protection « (immunitas atque tuitio). ${ }^{38}$ This division of monastic exemption into

38 See Rosenwein, Negotiating Space, 132; Felten, Äbte und Laienäbte im Frankenreich, 190ff.; Stengel, Immunität in Deutschland, 433-437. 
two complementary - yet distinctive - categories can be seen in December 777, when Abbot Fulrad of Saint-Denis was granted simmunity< for the monastery of Salonnes, located in the Moselle region of northern Francia. Confirming decisions made at the earlier-held council in Paderborn, Charlemagne decreed that the Frankish monastery should be placed directly "under the immunity and privilege of Saint-Denis ..." He went further by stating that this religious house should also be placed »under the protection [tuitio] and defense [defensio] of the king and his leading men without impediment from the bishop of Metz. « ${ }^{39}$

According to the Frankish diploma, Bishop Angilram of Metz willingly conceded these unique freedoms to the monastic community and its abbot, thereby openly limiting his authority and jurisdiction. When Charlemagne asked the bishop whether he truly consented to these privileges, he replied that "he did not deny it (ipsa nullatenus denegavit). Neither the bishop "nor his successors nor any archdeacons or missi from his church at Metz could exercise the bishop's right to do ordinations or bless the chrism and altars at Salonnes unless asked to do so by the abbot of Saint-Denis. $\aleph^{40}$ From this point onward, the responsibility of care for ecclesiastical properties and persons belonged exclusively inside the cloister walls. While not entirely removing Salonnes from episcopal care and responsibility, this particular exemption shifted the governance of this medieval monastery towards the monks living there.

The normative character of exemption thus evolved with the novel introduction of protection into the texts under the Merovingian rulers of Francia, and its subsequent elaboration by the Carolingians. ${ }^{41}$ Exemption was transformed from the exclusively fiscal concerns exhibited in late imperial Rome towards promises of spiritual and administrative freedoms. ${ }^{42}$ This institutional growth began with grants for monasteries and churches, which had become a prominent and practical dimension of Frankish governance after the sixth century. ${ }^{43}$ According to the surplus of protective vocabulary in the charter evidence from the eighth and ninth centuries, moreover, exemption was being framed by a new rhetorical and legal dimension: a new idiom of Frankish governance that increasingly emphasised peace, secu-

39 Die Urkunden Pippins, Karlmanns und Karls des Großen, no. 118, ed. Mühlbacher, 165. For the earlier grant by Pope Stephen II, see Grosse, Papsturkunden in Frankreich, nos. 2a-b, 67-70. See also Schwarz, Iurisdicio und Condicio, 96.

40 See Latin text in Rosenwein, Negotiating Space, appendix 3, 225.

41 See Blumenstock, Der päpstliche Schutz im Mittelalter, 18ff. For various arguments about its connection to the judicial and patrimonial privileges granted to monasteries in the eighth century, see especially Heinrich Appelt; Hans Hirsch; Magnou-Nortier, Josef Semmler, Alexander Murray, Walter Goffart, and Barbara Rosenwein. For a thorough analysis of immunities from the time of Louis the Pious, see Stengel, Immunität in Deutschland, ch. 1, 2.

42 For its Roman meaning, see especially Murray, Merovingian Immunity Revisited, 913-928.

43 For an excellent case study, see Ewig, Privileg des Bischofs Berthefrid, 538-583. Cf. Codex Justinianus 1.3.16, ed. Kruegger, 32. Rosenwein, Francia and Polynesia, 373. 
rity, tranquillity, and stability through tuitio, defensio, and mundeburdium. ${ }^{44}$ While the key political players in this negotiation remained unchanged - the monks, the bishop and the king - the commodity on offer (i.e., protection) served to re-define the exemption's central character and inherent use-value.

This institutional change was permanent and reoccurring. Monasteries that were successful in acquiring such privileges became - as a direct consequence - more active in upholding and asserting them. From the monks' perspective, it was necessary to confirm the various claims to autonomy and patrimony professed in these charters, sometimes as a matter of political expediency. ${ }^{45}$ The existence and organisation of monastic cartularies, which began in the late eleventh and early twelfth centuries in West Francia, demonstrate clearly the exemption's importance in establishing authoritative connections with local ecclesiastical and secular powers. ${ }^{46} \mathrm{~A}$ monastery's heritage, internal development, and prosperity was fostered through such external (allied) relationships; in this way, through their initial granting and subsequent confirmation(s), monastic exemptions maintained a traditional role in preserving the kingdom's strength and stability. With the added promise of protection, they also came to function as a more secure guarantee of monastic rights and liberties.

\section{Monastic exemption and the papacy}

The papacy in Rome understood this potential exceedingly well. Like the Frankish kings and bishops before them, early medieval popes had been issuing exemption privileges to monasteries for centuries. Bearing in mind the ad hoc and ad personam factors that invariably shaped the day-to-day business of monastic exemption, it is worth asking how the new emphasis on protection in the privileges allowed the papacy »to become a more important player. ${ }^{47}$ This question cannot be isolated from the episcopal and secular practices outlined above, but has to be viewed as the next stage of an evolutionary process of monastic rights and liberties. The changing dimensions of exemption are part of a much longer institutional development - a political and jurisdictional exercise that evolved over time, under different political leadership, and with increasing experience, want, and need..$^{48}$ Avoiding the pitfall of

44 Die Urkunden Pippins, Karlmanns und Karls des Großen, no. 178, ed. Mühlbacher, 240 (Caunes); ie Urkunden Pippins, Karlmanns und Karls des Großen, no. 264, ed. Mühlbacher, 384 (St Peter at Monte Piciaculi); Die Urkunden Lothars I. und Lothars II., ed. Schieffer, no. 32, 109 (Nonantola); Die Urkunden Lothars I. und Lothars II., ed. Schieffer, no. 51, 147-148 (Farfa); Die Urkunden Lothars I. und Lothars II., ed. Schieffer, no.134, 299 (Cruas); Die Urkunden Lothars I. und Lothars II., ed. Schieffer, no. 200, 354 (St-Maximian at Trier); and Die Urkunden Ludwigs II., ed. Wanner, nos. 31 (p. 129) and 42 (p. 152) (Bobbio). The remaining charters of Louis the German and Charles III provide characteristically similar privileges for monasteries like Klempten (Die Urkunden Ludwigs des Deutschen, Karlmanns und Ludwigs des Jüngeren, ed. Kehr, no. 107, 155), Hersfeld (Die Urkunden Ludwigs des Deutschen, Karlmanns und Ludwigs des Jüngeren, ed. Kehr, no. 32, 40-41), Herisi (Die Urkunden Ludwigs des Deutschen, Karlmanns und Ludwigs des Jüngeren, ed. Kehr, no. 137, 191), Saint-Maur-des-Fossés (Die Urkunden Pippins, Karlmanns und Karls des Großen, no. 149, ed. Mühlbacher, 241), and Farfa (Die Urkunden Pippins, Karlmanns und Karls des Großen, no. 179, ed. Mühlbacher, 274).

45 Berkhofer, Day of Reckoning, 57. See also Lohrmann, Formen der Enumeratio bonorum, 281-311.

46 See especially Bouchard, Rewriting Saints and Ancestors, ch. 1, 2; Bouchard, Monastic Cartularies, 22-32.

47 Rosenwein, Negotiating Space, 134.

48 Kölzer, Bonifatius und Fulda, 43; Kéry, Klosterfreiheit und päpstliche Organisationsgewalt, 93. 
anachronism, the critical questions remain: whether a political endgame was ever imagined in this historical process, or whether the papacy ever marshalled a >concrete strategy intensifying practice, organisation, or jurisdictional claims before the eleventh century. ${ }^{49}$

The papacy achieved the status of a guarantor of monastic freedom and protection primarily through its administrative and legal role in confirming privileges, commonly entering into a relationship with a monastery after its foundation - that is, once the monastery was already established in the local community. In this respect, the papacy appears as a late third party to the negotiations, regularly usurping rights previously granted by and owed to bishops and kings. ${ }^{50}$ The majority of the formulaic charter evidence highlights the pope's (at first) marginal role in this regard. But the action itself can be interpreted as a firm demonstration of Roman power in the distant Christian provinces: confirming privileges of freedom and protection acknowledged and reinforced existing relationships between various monasteries and Rome.

It also forged many new relationships between individual popes, monks, and monasteries, whose political and judicial orientation towards Rome represents a break with tradition. The earliest example of this relationship is attributed to Pope Honorius I (625-638), who issued an exemption privilege to the northern Italian monastery of Bobbio in 628, effectively freeing it from the control of its diocesan bishop, Probus of Tortana. ${ }^{51}$ According to the contemporary Vita Columbani, the bishop was "trying to make the abbot and the monastery's livelihood subject to him. « $^{52}$ Unable to rely on the ecclesiastical agent who was meant to protect the monastery, the monks looked elsewhere for support; as the charter determines in principle, the defence of freedom from the bishop's interference lay exclusively with the pope in Rome. Susan Wood has argued that this form of protection was "not an alternative lordship, but moral support for a church's possessions and independence (which would require some exemption from episcopal authority as then manifesting itself). ${ }^{53}$ In truth, however, this powerful precedent eventually did give way to the idea of Rome's jurisdictional authority, which gradually came to embody the role of a centralised power. In other words, the language and promise of papal protection constituted a number of early medieval exemptions in the seventh and eighth centuries, establishing a longer pattern of Roman intervention..${ }^{54}$ And it existed and prevailed alongside episcopal and royal privileges of a similar nature, which political reality brings us back to our opening question of necessity and purpose.

49 Kéry, Klosterfreiheit und päpstliche Organisationsgewalt, 112-113, 84-85; Pfaff, Päpstliche Klosterexemtionen, 91.

50 E.g., Monte Cassino, Farfa, Fulda, Saint Denis, San Vincenzo a Volturno, Nonantola, Subiaco, Fleury, and Vézelay.

51 Codice diplomatico del monastero di San Colombano di Bobbio, I.10, ed. Cipolla, 100-103; Italia Pontificia 6/2, ed. Kehr, 249, no.6; Levison, England and the Continent, 109; Liber Diurnus, ed. Foerster, 77; Schwarz, Iurisdicio und Condicio, 58.

52 Vita Columbani,II.23, ed. Krusch, 281f.4 f.

53 Wood, Proprietary Church, 196.

54 Anton, Studien zu den Klosterprivilegien, 141. Some early examples from this period include Rebais in 637, where we find the expression B. Petri tuitio. In the last quarter of the seventh century (678-681), Pope Agatho promised the English monasteries of London and Chertsey the protection (tuitio) of the apostolic see. Pope Sergius I granted privileges for the English monastery of Malmesbury (c. 701), and Pope John VII for Farfa (705), which placed these monasteries firmly ssub jurisdictione atque tuitione r of the apostolic see. Employing similar language in their charters, false privileges were also issued under the names of Popes Benedict II for Saint-Gilles (JL †2127), Stephen II for Fulda (JL †2319), Vinzenzo a Volturno (JL †2320), Figeac (JL †2321), and St Vaast d’Arras (JL †2328). 
What did papal protection really offer monasteries? As evidence of this evolving relationship, consider the royal monastery of Fulda, which famously acquired its first papal exemption in November $751 .{ }^{55}$ Sought on the monks' behalf by the missionary and legate to Germany, Saint Boniface, the privileges that Pope Zacharias granted were intended to limit the bishops of Mainz and Würzburg from interfering in the community's internal governance. ${ }^{56} \mathrm{Com}$ plying with Boniface's wish, the pope expressly forbade "any priest of any church except the apostolic see to have any rights whatsoever in the aforesaid monastery, so that no one shall presume, except by invitation of the abbot, even to celebrate Mass there, and so that the monastery shall firm and forever be endowed with all rights implied in the apostolic privilege. ${ }^{57}$ Despite this papal exemption, the monastery of Fulda remained threatened by the overbearing bishop of Mainz (Lull), prompting King Pippin to place it under his direct protection in the mid-76os. According to the Vita Sturmi, a biography of the monastery's first abbot, the Frankish ruler not only honoured the "privilege that blessed Pope Zacharias, the supreme pontiff of the apostolic see, had formerly granted to the holy Boniface«, but he also »ordered that the well-being and defence [defensio] of the monastery be placed in the hands of no one other than the king ${ }^{\prime \prime 5^{8}}$

The papacy played an active role in executing and achieving this outcome. With the help of its privileges, Fulda effectively traded episcopal power for royal protection. ${ }^{59}$ In practice, Pope Zacharias both enabled and facilitated this relationship, leaving the Frankish ruler as the de facto enforcer of Fulda's exemption privileges. The former's authority made the connection possible, with political, spiritual, and fiscal profits to be gained on both sides of the arrangement. ${ }^{60}$

The explicit politicization of papal protection transformed the character of monastic exemption permanently. For many historians, these promises of tuitio to monasteries both north and south of the Alps were effective weapons of papal power and monastic freedom, offering a viable way to "monopolise control ${ }^{61}$ and express "the Church's growing autonomy. ${ }^{62}{ }^{2}$ This interpretation builds on the oft-cited, and still important, work of Alfred

55 Liber Diurnus, ed. Foerster, 32. For a thorough study of Fulda, see Rathsack, Fuldaer Fälschungen, and Kéry, Klosterexemtion in der Einöde?, 75-110. See also Lübeck, Exemption des Klosters Fulda, 132-153, and Lübeck, Fuldaer Abtswahlprivilegien, 340-389.

56 Codex diplomaticus Fuldensis 4a-b, ed. Dronke, 2-4.

57 S. Bonifatii et Lulli Epistolae, ep. 89, 203-205.

58 Vita S. Sturmi Abbatis Fuldensis, ed. Pertz, ch. 20, 375. Raaijmakers, Making of the Monastic Community, 51.

59 De Jong, Carolingian Monasticism, 624.

60 The exemption for Fulda - which also formed the basis of Formula 32 in the Liber Diurnus - inspired numerous other confirmations given to this monastery by Popes Stephen II (784), Hadrian I (784), Leo III (811), Gregory IV (828), Leo IV (850), Benedict III (857), Nicholas I (859), John VIII (875), Marinus (943), Agapitus II (948 and 950), John XII (961), and Clement III. The model for this exemption inspired subsequent charters for the monasteries of Saint Salvator (Brescia), Santa Maria (Pfäffers), Hersfeld, Reichenau, Santa Maria in Bagno, Gandersheim, Saints Germanus and Michael (Cuxa), San Martino (near Pavia), Saint Caecilia (Montserrat), Saint Peter (Rodas), Sant'Antimo, Saint Salvator (Montamiata), Saint Genesii (Besalu), Lorsch, Saints Salvator and Benedict (Leno), San Cugat del Vallés, Fruttuaria, and Monte Cassino. See Liber Diurnus Romanorum Pontificum 32, ed. Foerster, 93-94; Santifaller, Verwendung des Liber diurnus, 299.

61 Boureau, Privilege in Medieval Societies, 623.

62 Boureau, Privilege in Medieval Societies, 625. 
Blumenstock, Paul Fabre, Hans Hirsch, Heinrich Appelt, Hans Hubert Anton, Edward Stengel, Georg Schreiber, Willy Szaivert, and Ludwig Falkenstein (among others), whose version of exemption history and papal protection explains the papacy's broader institutional and jurisdictional development in the early Middle Ages. ${ }^{63}$ But it frames the question in practical rather than ideological terms, advancing the argument for the papacy's conscious involvement in the process, which inevitably shaped the contemporary meaning and value of exemption privileges for all concerned parties. Whether an exempt monastery became directly subordinate to the papal Curia as a result is a complex political question, contingent upon the community's individual circumstances and negotiating abilities. ${ }^{64}$ But it is accurate to say that this growing institutional practice introduced a powerful political dimension to medieval papal-monastic governance. Binding the monastery more firmly to the spiritual centre in Rome, the papacy's offer of protection gradually became a central and normative characteristic of monastic exemption privileges.

This monastic orientation towards Rome, however, was not a foregone conclusion. That is, its growing practice was never inevitable in the longer and intersecting histories of medieval monasticism and the papacy. Yet it was not fate that brought these two together; forging and sustaining a special relationship with the popes in Rome was an intensely political and strategic game. Gerd Tellenbach rightly warned against any notion that "popes are supposed to have made use of exempt monasteries in a planned action aimed at bringing their claims of universal episcopacy to bear. ${ }^{65}$ As recent studies of the medieval papacy suggest, >contingency played a far more decisive role in determining its future direction and historical development. ${ }^{66}$ This interpretation counters any notion of a coherent papal policy, strategy, or movement of exemption. But it does not abrogate evolutionary forces, whose continued practice represents what Egon Boshof rightly characterized as a straditio Romanar (or `Roman tradition $)$ ) ${ }^{67}$ In short: the cumulative practice of exemption in the early Middle Ages, powered by the papacy's growing organizational skills, jurisdictional claims, and authoritative leadership, added significant value to what can be called a commodity of political exchange. Ostensibly limiting local and regional interference, whether secular or ecclesiastical, papal exemptions bolstered the monastery's independence. They also bound the monks more closely to the apostolic see, forging relationships with Rome that redressed existing political structures and hierarchies. ${ }^{68}$

63 See bibliography.

64 Szaivert, Entstehung und Entwicklung, 296.

65 Tellenbach, Church in Western Europe, 114.

66 See especially Noble, Narratives of Papal History, 18; Larson, Introduction, 1.

67 Boshof, Traditio Romana und Papstschutz.

68 See especially Lemarignier, Structures monastiques; Lemarignier, L'Exemption monastique; and Lemarignier, Étude sur les privilèges. 


\section{Conclusion}

The offer of apostolic protection augmented the Frankish exemption privileges that had been granted to monasteries by kings and bishops in the seventh, eighth, and ninth centuries. ${ }^{69}$ While the Carolingians were also in the business of providing ecclesiastical protection (Königschutz) ${ }^{70}$, the papacy was offering a more substantial, spiritual, and arguably permanent solution. From the ninth century onward, Rome's protection was considered by monastic communities to be more static, stable, and seemingly desirable than what kings could offer - far more than just a »deliberate echo of the royal protection ceremonies. ${ }^{71}$ Distinguishing itself from earlier episcopal practice, moreover, the papacy was never setting a limit to its authority by granting privileges. Rather the opposite was occuring, as medieval popes increasingly capitalised on a growing demand for exemption from episcopal intervention from the monasteries. Protection, as this article has suggested, was not only a key driver in the delivery of exemption - it was central to the institution's development, contemporary value, and normative character.

69 Paul I for S. Salvatore and Saint Giulia in Brescia (762) (Regesta Pontificium Romanorum, ed. Jaffé et al., 2350; Italia Pontificia 6/1, ed. Kehr, 320, no. 1). In 971, Pope John XIII issued specific privileges for Glastonbury, which gave the monastery power to ordain its monks while restricting any outside interference in matters of correction (JL 3751; PL 135:984). Pope Stephen VIII for Vincenzo a Volturno (930) (JL 3581). In 1022, Pope Benedict VII recognised S. Sophia in Benevento as subject to the apostolic see and thus exempt from the authority of Montecassino (Patrologia Latina 139, ed. Migne, 1625; JL 4037). In 963, Pope Leo VIII granted Montmajour (JL 3702; PL 134:994 - Si semper sunt (Form 77)]. Gregory VI confirmed the privileges of St Peter in Perugia in 1045 (JL 4123). S. Salvatoris in Insula (Senensi) 1050 - confirmed (JL 4231). Ditto for Amiate (JL 4232) and St Maurice-d'Agaune in 1050 (JL 4246). In 1057, Stephen IX confirmed the possessions and privileges of S Prosper in Reggio (JL 4376); the same was done in 1063 for Fruttuaria (JL 4499). In 1071, under Alexander II, the monastery of Saints Peter and Paul at Cremona had its liberty confirmed, detailing that payment of the annual census should be paid to Milan (JL 4687).

70 Consider the examples of St Hilaire-de-Carcassonne (814/15), St Peter in Ghent (815), St Wandrille (815), Montolieu (815), St-Maur-des-Fossés (816), Cornelimünster (817), Belle Celle (819), Conques (819), Montier-en-Der (827), St Colombe in Sens (833), and St Gallen (854). See Semmler, Traditio und Königsschutz, 12-13; Boshof, Traditio Romana und Papstschutz, $5 \mathrm{ff}$.

71 Hirsch, Untersuchungen zur Geschichte, 387. 


\section{References}

Anton, Hans Hubert, Studien zu den Klosterprivilegien der Päpste im frühen Mittelalter unter besonderer Berücksichtigung der Privilegierung von St. Maurice d'Agaune (Berlin, 1975).

Appelt, Heinrich, Die Anfänge des päpstlichen Schutzes, Mitteilungen des Instituts für österreichische Geschichtsforschung 62 (1954) 101-111.

Berkhofer III, Robert F., Day of Reckoning: Power and Accountability in Medieval France (Philadelphia, 2004).

Bittermann, Helen Robbins, The Influence of Irish Monks on Merovingian Diocesan Organization, The American Historical Review 40 (1935) 232-245.

Blumenstock, Alfred, Der päpstliche Schutz im Mittelalter (Innsbruck, 1890).

Boshof, Egon, Traditio Romana und Papstschutz im 9. Jahrhundert, in: Egon Boshof and Heinz Wolter (eds.), Rechtsgeschichtlich-diplomatische Studien zu frühmittelalterlichen Papsturkunden (Cologne, 1976) 1-100.

Bouchard, Constance Brittain, Rewriting Saints and Ancestors: Memory and Forgetting in France, 500-1200 (Philadelphia, 2014).

Bouchard, Constance Brittain, Monastic Cartularies: Organizing Eternity, in: Adam J. Kosto and Anders Winroth (eds.), Charters, Cartularies, and Archives: The Preservation and Transmission of Documents in the Medieval West (Toronto, 1999) 22-32.

Boureau, Alain, Privilege in Medieval Societies from the Twelfth to the Fourteenth Centuries, or: How the Exception Proves the Rule, in: Peter Linehan and Janet L. Nelson (eds.), The Medieval World (London, 2001) 621-634.

Brackmann, Albert, Zur politischen Bedeutung der kluniazensischen Bewegung (Darmstadt, 1955).

Cantor, Norman, The Crisis of Western Monasticism, The American Historical Review 66 (1960) 47-67.

Cartulaire de l'abbaye de Gorze, ed. Armand d'Herbomez (Paris, 1898).

The Cartulary of Montier-en-Der, 666-1129, ed. and trans. Constance Brittain Bouchard (Toronto, 2004).

Codex diplomaticus Fuldensis, ed. Ernst Friedrich Johann Dronke (Cassel, 1850; reprint Aalen, 1962).

Codex Justinianus, ed. Paul Krueger (Berlin, 1877).

Codice diplomatico del monastero di San Colombano di Bobbio, ed. Carlo Cipolla, I (Rome, 1918).

Concilia aevi Karolini, ed. Albert Werminghoff, MGH Concilia 2.1 (Hanover, 1906).

Concilia Galliae, a.314-a.506, ed. Charles Munier, CCSL 148 (Turnhout, 1963).

Cowdrey, Herbert Edward John, The Cluniacs and the Gregorian Reform (Oxford, 1970).

de Jong, Mayke, Carolingian Monasticism: The Power of Prayer, in: Rosamond McKitterick (ed.), The New Cambridge Medieval History, c.700-c.90o, vol. 2 (Cambridge, 1995) 622653.

Diplomata, chartae, epistolae, leges, aliaque ad res Gallo-Francicas spectantia, ed. Jean-Marie Pardessus, 2 vols. (Paris, 1843-1849).

Diplomatum imperii I, ed. Georg Heinrich Pertz, MGH Diplomatum 1 (Hanover, 1872).

Dunn, Marilyn, The Emergence of Monasticism: From the Desert Fathers to the Early Middle Ages (Oxford, 2000). 
Ewig, Eugen, Beobachtungen zu den Klosterprivilegien des 7. und frühen 8. Jahrhunderts, in: Gerd Tellenbach, Karl Schmid, and Josef Fleckenstein (eds.), Adel und Kirche. Gerd Tellenbach zum 65. Geburtstag dargebracht von Freunden und Schülern (Freiburg, 1968) 52-65; reprinted in: Hartmut Atsma (ed.), Spätantikes und fränkisches Gallien, Vol. 2 (Munich, 1979) 411-426.

Ewig, Eugen, Das Formular von Rebais und die Bischofsprivilegien der Merowingerzeit, in: Hartmut Atsma (ed.), Spätantikes und fränkisches Gallien, Vol. 2. (Munich, 1979) 456-484.

Ewig, Eugen, Das Privileg des Bischofs Berthefrid von Amiens für Corbie von 664 und die Klosterpolitik der Königin Balthild, in: Hartmut Atsma (ed.), Spätantikes und fränkisches Gallien, Vol. 2. (Munich, 1979) 538-583.

Fabre, Paul, Étude sur le Liber censuum de l'Église romaine (Paris, 1892).

Falkenstein, Ludwig, La papauté et les abbayes françaises aux XIe et XIIe siècles: exemption et protection apostolique (Paris, 1997).

Felten, Franz J., Äbte und Laienäbte im Frankenreich: Studie zum Verhältnis von Staat und Kirche im früheren Mittelalter (Stuttgart, 1980).

Fliche, Augustin, La réforme Grégorienne, 3 vols. (Louvain, 1924).

Fox, Yaniv, The Bishop and the Monk: Desiderius of Vienne and the Columbanian Movement, Early Medieval Europe 20 (2012) 176-194.

Goetting, Hans, Die klösterliche Exemtion in Nord- und Mitteldeutschland vom 8. bis zum 15. Jahrhundert, Archiv für Urkundenforschung 14 (1936) 105-187.

Goffart, Walter, The Privilege of Nicholas I for St Calais: A New Theory, Revue Bénédictine 71 (1961) 287-337.

Grosse, Rolf (eds.), Papsturkunden in Frankreich. Neue Folge. Vol. 9: Diözese Paris II, Abtei Saint-Denis, Abhandlungen der Akademie der Wissenschaften in Göttingen, Philologisch-historische Klasse, Dritte Folge, Nr. 225 (Göttingen, 1998).

Hallinger, Kassius, Regula Benedicti 64 und die Wahlgewohnheiten des 6. - 12. Jahrhunderts, in: Herbert Bannert, Rudolf Hanslik and Johannes Divjak (eds.), Latinität und alte Kirche, Festschrift Rudolf Hanslik (Vienna, 1977) 109-137.

Hirsch, Hans, Untersuchungen zur Geschichte des päpstlichen Schutzes, Mitteilungen des Österreichischen Instituts für Geschichtsforschung 54/3-4 (1942) 363-433.

Italia pontificia; sive, Repertorivm privilegiorvm et literarvm a romanis pontificibvs ante annvm MCLXXXXVIII Italiae ecclesiis, monasteriis, civitativvs singvlisqve personis concessorvm, Vol. 6/1-2, ed. Paul Fridolin Kehr (Berlin, 1913)

Kéry, Lotte, Klosterfreiheit und päpstliche Organisationsgewalt. Exemtion als Herrschaftsinstrument des Papsttums?, in: Jochen Johrendt and Harald Müller (eds.), Rom und die Regionen. Studien zur Homogenisierung der lateinischen Kirche im Hochmittelalter (Munich, 2012) 83-144.

Kéry, Lotte, Klosterexemtion in der Einöde? Bonifatius und das Privileg des Papstes Zacharias für Fulda (751), Archiv für mittelrheinische Kirchengeschichte 60 (2008) 75-110.

Knowles, David, The Monastic Order in England: A History of Its Development from the Times of St Dunstan to the Fourth Lateran Council (2nd edition), (Cambridge, 1963).

Kölzer, Theo, Bonifatius und Fulda: Rechtliche, diplomatische und kulturelle Aspekte, Archiv für mittelrheinische Kirchengeschichte 57 (2005) 25-53.

La règle de Saint Benoît, ed. Adalbert de Vogüé and Jean Neufville, 7 vols. (Paris, 1972).

La règle du maître, ed. and trans. Adalbert de Vogüé, 2 vols. (Paris, 1964).

Larson, Atria, Introduction, in: Keith Sisson and Atria A. Larson (eds.), A Companion to the Medieval Papacy: Growth of an Ideology and Institution (Leiden, 2016) 1-16. 
Lemarignier, Jean-François, Political and Monastic Structures in France at the End of the Tenth and the Beginning of the Eleventh Century, in: Fredric L. Cheyette (ed.), Lordship and Community in Medieval Europe (New York, 1968) 100-127.

Lemarignier, Jean-François, Structures monastiques et structures politiques dans la France de la fin du Xè et des débuts du XIè siècle, in: Il monachesimo nell'alto medioevo e la formazione della civilità occidentale (Spoleto, 1957) 357-400.

Lemarignier, Jean-François, L'Exemption monastique et les origines de la réforme grégorienne., in: A Cluny. Congrès scientifique en l'honneur des Saints Abbes Odon et Odilon, 9-11 juillet 1949. Travaux des Congrès (Dijon, 1950) 288-340.

Lemarignier, Jean-François, Étude sur les privilèges d'exemption et de juridiction ecclésiastique des abbayes normandes depuis les origines jusqu'en 1140 (Paris, 1937).

Levison, Wilhelm, England and the Continent in the Eighth Century (Oxford, 1946).

Liber Diurnus Romanorum Pontificum, ed. Hans Foerster (Bern, 1958).

Lohrmann, Dietrich, Formen der Enumeratio bonorum in Bischofs-, Papst- und Herrscherurkunden (9.-12. Jahrhundert), Archiv für Diplomatik 26 (1980) 281-311.

Lübeck, Konrad, Die Exemption des Klosters Fulda bis zur Mitte des 11. Jh., Studien und Mitteilung zur Geschichte des Benediktiner-Ordens 55 (1937) 132-153.

Lübeck, Konrad, Die Fuldaer Abtswahlprivilegien, Zeitschrift der Savigny-Stiftung für Rechtsgeschichte, kanonistische Abteilung 35 (1948) 340-389.

Magnou-Nortier, Elisabeth, Étude sur le privilège d'immunité du IVe au XIe siècle, Revue Mabillon 60 (1984) 465-512.

Marculfi Formulae, ed. Charles Zeumer, MGH Leges, Formulae Merowingici et Karolii aevi (Hanover, 1886).

Murray, Alexander Callander, Merovingian Immunity Revisited, History Compass 8 (2010) 913-928.

Noble, Thomas F.X., Narratives of Papal History, in: Keith Sisson and Atria A. Larson (eds.), A Companion to the Medieval Papacy: Growth of an Ideology and Institution (Leiden, 2016) 17-33.

O'Hara, Alexander, The Vita Columbani in Merovingian Gaul, Early Medieval Europe 17 (2009) 126-153.

Patrologia Latina 139, ed. Jean-Paul Migne (Paris, 1880).

Pfaff, Volkert, Die päpstlichen Klosterexemtionen in Italien bis zum Ende des zwölften Jahrhunderts. Zeitschrift der Savigny-Stiftung für Rechtsgeschichte, kanonistische Abteilung 72 (1986) 76-114.

Pontal, Odette, Die Synoden im Merowingerreich (Paderborn, 1986).

Price, Richard and Gaddis, Michael, The Acts of the Council of Chalcedon, 3 vols. (Liverpool, 2005).

Raaijmakers, Janneke, The Making of the Monastic Community of Fulda, c. 744-c.9oo (Cambridge, 2012).

Rathsack, Mogens, Die Fuldaer Fälschungen: eine rechtshistorische Analyse der päpstlichen Privilegien des Klosters Fulda von 751 bis ca. 1158, 2 vols. (Stuttgart, 1989).

Regesta Pontificium Romanorum ab condita ecclesia ad annum post Christum natum 1198, ed. Philipp Jaffé, Samuel Löwenfeld, Ferdinand Kaltenbrunner, Paul Ewald, 2 vols. (Leipzig, 1885-1888).

Remensnyder, Amy G., Remembering Kings Past: Monastic Foundation Legends in Medieval Southern France (Ithaca, N.Y., 1995). 
Rio, Alice, The Formularies of Angers and Marculf: Two Merovingian Legal Handbooks (Liverpool, 2008).

Rosenwein, Barbara H., Francia and Polynesia: Rethinking Anthropological Approaches, in: Gadi Algazi, Valentin Groebner and Bernhard Jussen (eds.), Negotiating the Gift: PreModern Figurations of Exchange (Göttingen, 2003) 361-379.

Rosenwein, Barbara H., Negotiating Space: Power, Restraint, and Privileges of Immunity in Early Medieval Europe (Ithaca, N.Y., 1999).

Rosenwein, Barbara H., Association through Exemption: Saint-Denis, Salonnes, and Metz, in: Hagen Keller and Franz Neiske (eds.), Vom Kloster zum Klosterverband. Das Werkzeug der Schriftlichkeit (Munich, 1997) 68-87.

Sackur, Ernst, Die Cluniacenser in ihrer kirchlichen und allgemeingeschichtlichen Wirksamkeit bis zur Mitte des elften Jahrhunderts, 2 vols. (Halle an der Saale, 1892).

S. Bonifatii et Lulli Epistolae, MGH Epp. 3 (Berlin, 1892) 215-384.

Santifaller, Leo, Die Verwendung des Liber diurnus in den Privilegien der Päpste von den Anfängen bis zum Ende des 11. Jahrhunderts, Mitteilung des Oesterreichischen Instituts für Geschichtsforschung 49 (1935) 225-366.

Schreiber, Georg, Kurie und Kloster im 12. Jahrhundert: Studien zur Privilegierung, Verfassung und besonders zum Eigenkirchenwesen de vorfranziskanischen Orden vornehmlich auf Grund der Papsturkunden von Paschalis II. bis auf Lucius III. (1099-1181), 2 vols. (Stuttgart, 1910).

Schreiber, Georg, Kluny und die Eigenkirche. Zur Würdigung der Traditionsnotizen des hochmittelalterlichen Frankreich, Archiv für Urkundenforschung 17 (1942) 412-418.

Schwarz, Wilhelm, Iurisdicio und Condicio. Eine Untersuchung zu den privilegia libertatis der Klöster, Zeitschrift der Savigny-Stiftung für Rechtsgeschichte, kanonistische Abteilung 45 (1959) 34-98.

Semmler, Josef, Traditio und Königsschutz. Studien zur Geschichte der königlichen monasteria, Zeitschrift der Savigny-Stiftung für Rechtsgeschichte, kanonistische Abteilung 45 (1959) 1-33.

Stengel, Edmund E., Die Immunität in Deutschland bis zum Ende des 11. Jahrhunderts, Diplomatik der deutschen Immunitäts-Privilegien von 9. bis zum Ende des 11. Jahrhunderts (Innsbruck, 1910).

Szaivart, Willy, Die Entstehung und Entwicklung der Klosterexemption bis zum Ausgang des 11. Jahrhunderts, Mitteilungen des Instituts für österreichische Geschichtsforschung 59 (1951) 265-298.

Tellenbach, Gerd, The Church in Western Europe from the Tenth to the Early Twelfth Century, trans. Timothy Reuter (Cambridge, 1993).

Tellenbach, Gerd, Church, State, and Christian Society at the Time of the Investiture Contest, trans. Ralph Francis Bennett (Oxford, 1940).

Ueding, Leo, Die Kanones von Chalkedon in ihrer Bedeutung für Monchtum und Klerus, in: Alois Grillmeier and Heinrich Bacht (eds.), Das Konzil von Chalcedon. Geschichte und Gegenwart, Vol. 2 (Würzburg, 1951) 569-676.

Die Urkunden Lothars I. und Lothars II., ed. Theodor Schieffer, MGH Die Urkunden der Karolinger III (Berlin, 1966).

Die Urkunden Ludwigs II., ed. Konrad Wanner, MGH Die Urkunden der Karolinger 4 (München, 1994).

Die Urkunden Ludwigs des Deutschen, Karlmanns und Ludwigs des Jüngeren, ed. Paul Fridolin Kehr, MGH Die Urkunden der deutschen Karolinger 1 (Berlin, 1934). 
Die Urkunden Pippins, Karlmanns und Karls des Großen, ed. Engelbert Mühlbacher, MGH Die Urkunden der Karolinger 1 (Hanover, 1906).

Wickham, Chris, and Reuter, Timothy, Introduction, in: Wendy Davies and Paul Fouracre (eds.), Property and Power in the Early Middle Ages (Cambridge, 1995) 1-16.

Wood, Ian N., The Merovingian Kingdoms, 450-751 (London, 1994).

Wood, Susan, The Proprietary Church in the Medieval West (Oxford, 2006).

Ionae Vita Columbani abbatis discipulorumque eius libri duo auctore Iona, in: Ionae Vitae Sanctorum Columbani, Vedastis, Iohannis, ed. Bruno Krusch, MGH SS rerum Germanicarum in usum scholarum separatim editi 37 (Hanover-Leipzig, 1905) 1-294.

Eigilis vita S. Sturmi abbatis Fuldensis, ed. Georg Pertz, MGH SS 2 (Hanover, 1829) 365-377.

Abbreviations

JE = Jaffé, Ewald: Regesta Pontificium Romanorum.

JL = Jaffé, Löwenfeld: Regesta Pontificium Romanorum. 